\title{
PERTUMBUHAN SENGON SOLOMON DAN RESPONNYA TERHADAP PENYAKIT KARAT TUMOR DI BONDOWOSO, JAWA TIMUR
}

Growth of sengon Solomon and its response to gall rusts diseases in Bondowoso, East Java

\author{
Dedi Setiadi, Liliana Baskorowati, dan Mudji Susanto \\ Balai Besar Penelitian Bioteknologi dan Pemuliaan Tanaman Hutan \\ Jl. Palagan Tentara Pelajar Km 15, Purwobinangun, Pakem, Sleman, Yogyakarta 55582 \\ e-mail: Setiadi2009@yahoo.com
}

\begin{abstract}
A provenance stands of sengon Solomon (Falcataria moluccana (Miq.) Barneby \& JW Grimes was establishhed in Bondowoso, East Java in 2011. One provenance seed consisting of 25 families originated from Solomon Island were used in this trial. Provenance stands was designed by rows column design (incomplete block) involving 8 blocks, 4 trees per plot (plot tree) with a spacing of $3 m \times 2 \mathrm{~m}$. Several characters were observed i.e: survival rate, height, diameter and the presence of gall rust diseases; the observations were undertaken every 6 months from 6 months old up to the age of 18 months. The results showed that the mean of survival rates ranging from $75 \%$ to $90 \%$; with the average survival rate of $84.83 \%$ (6 months), $83.26 \%$ (12 months) and 81.05\% (18 months). The mean height and diameter of 6 months old $(2.42 \mathrm{~m}, 2.97 \mathrm{~cm}), 12$ months old $(4.74 \mathrm{~m}, 5.56 \mathrm{~cm})$, and 18 months old $(7.35 \mathrm{~m}, 7.39 \mathrm{~cm})$. Varian analysis of height, diameter, disease severity and intensity showed that there were no significant differences between families. All of families attacked by gall rust disease, however family number 2, 8 and 23 showed the lowest respond of attack compared to other families. Therefore, those families can be recommended for future development in terms of toleration to the gall rust disease.
\end{abstract}

Keywords: Falcataria moluccana, gall rust disease, growth, seed source

\begin{abstract}
ABSTRAK
Tegakan provenan sengon Solomon (Falcataria moluccana (Miq.) Barneby \& J.W. Grimes) telah dibangun di Bondowoso, Jawa Timur pada tahun 2011; dengan menggunakan benih yang berasal dari Solomon sebanyak 25 famili. Tegakan provenan dirancang menggunakan rancangan baris kolom (blok tidak lengkap) dengan 8 blok, 4 pohon per plot (tree plot) dan jarak tanam $3 \mathrm{~m}$ x $2 \mathrm{~m}$. Karakter yang diamati adalah persen hidup, tinggi, diameter dan serangan penyakit karat tumor; pengamatan dilakukan setiap 6 bulan sekali, mulai dari umur 6 sampai 18 bulan. Hasil pengamatan menunjukkan bahwa rerata persen hidup berkisar antara $75 \%$ hingga $90 \%$, pada umur 6 bulan $(84,83 \%), 12$ bulan $(83,26 \%)$ dan 18 bulan $(81,05 \%)$. Rerata tinggi dan diameter umur 6 bulan $(2,42 \mathrm{~m}, 2,97 \mathrm{~cm}), 12$ bulan $(4,74 \mathrm{~m}, 5,56 \mathrm{~cm})$, dan 18 bulan $(7,35 \mathrm{~m}, 7,39 \mathrm{~cm})$. Analisis varian tinggi, diameter, intensitas dan luas serangan penyakit menunjukkan perbedaan yang tidak nyata antara famili. Secara umum, semua famili sengon Solomon terserang penyakit karat tumor. Namun demikian famili nomer 2; 8; dan 23 menunjukkan intensitas dan luas serangan penyakit yang paling kecil, dibandingkan dengan famili lainnya. Dengan demikian famili-famili tersebut perlu mendapat perhatian secara
\end{abstract}


khusus dan menjadi pertimbangan untuk pengembangan lebih lanjut.

\section{Kata kunci : Falcataria moluccana, penyakit karat tumor, pertumbuhan, sumber benih}

\section{PENDAHULUAN}

Sengon (Falcataria moluccana

(Miq.) Barneby \& J.W. Grimes) secara alami tersebar di Maluku, Papua, Papua Nugini, Kep Solomon dan Bismark (Hidayat, 2002). Tanaman sengon juga banyak diminati oleh berbagai kalangan terutama petani di hutan rakyat. Masyarakat pada umumnya menggunakan pohon sengon dari umur 4 - 10 tahun, dengan diameter $10-45 \mathrm{~cm}$; dimana batang sengon tersebut sudah bernilai ekonomis (Widhana, 2011). Sedangkan Krisnawati $d k k$. (2011) menyatakan sengon yang berumur 5-10 tahun mempunyai tinggi rata-rata 9,9-27,9 $\mathrm{m}$, tegakan umur 12 tahun memiliki tinggi 15,3-36,2 m. Riap pertumbuhan sengon rata-rata mencapai 20 $\mathrm{m}^{3} / \mathrm{ha} /$ tahun, sedangkan sengon di hutan rakyat dengan pola usaha tani pertumbuhan riap tanaman sengon $16,78 \mathrm{~m}^{3} / \mathrm{ha} /$ tahun, dengan rata-rata produksi $134,23 \mathrm{~m}^{3} / \mathrm{ha}$ (Gunawan dkk., 2013). Namun demikian, tanaman sengon umur 7 tahun yang sudah terseleksi dengan perlakuan pertumbuhan riap mampu mencapai $27,26 \mathrm{~m}^{3} /$ ha/tahun, dengan produksi rata-rata mencapai 190,84 $\mathrm{m}^{3} /$ ha (Rimbawanto, 2008).

Berdasarkan hasil penelitian yang dilaporkan oleh Agus (2008) dalam Trubusid (2008), salah satu sengon yang memiliki pertumbuhan yang lebih cepat dibandingkan dengan sengon lokal adalah sengon provenan asal Solomon. Hasil penelitian Setiadi, $d k k$. (2014) menunjukkan bahwa jenis tanaman sengon Solomon sampai umur 12 bulan mempunyai pertumbuhan yang baik dengan rata-rata pertumbuhan tinggi $5,0 \mathrm{~m}$ dan diameter 5,7 cm. Sengon Solomon umur 20 bulan memiliki tinggi pohon rata-rata 12 meter dan diameter $12 \mathrm{~cm}$, sedangkan sengon lokal memiliki tinggi pohon ratarata $10 \mathrm{~m}$ dan diameter $9 \mathrm{~cm}$ (Trubusid, 2007). Hardiyanto (2010) menyebutkan pertumbuhan diameter sengon Solomon umur 2 th $(16 \mathrm{~cm}) ; 3$ th $(19 \mathrm{~cm})$ yang lebih besar dibandingkan dengan sengon lokal di Temanggung yaitu 2 th $(12 \mathrm{~cm}) ; 3$ th $(16 \mathrm{~cm})$. Lebih lanjut dikemukakan bahwa produktivitas sengon Solomon 3 kali lipat dibandingkan dengan sengon lokal yang saat 
ini banyak ditemukan di Indonesia khususnya pulau Jawa. Di Indonesia sendiri, sengon Solomon sangat jarang dibudidayakan oleh masyarakat karena benih yang harus didatangkan dari Solomon; dan beberapa tanaman sengon Solomon di daerah Kediri Jawa Timur (KPH Pandantoyo) maupun di Candiroto Jawa Tengah menunjukkan ketidakmampuan berbungga dan berbuah pada umur 8 tahun (Komunikasi pribadi, Dr Eko Bhakti Hardiyanto); dan tegakan tersebut ditebang untuk diambil produksi kayunya. Hal tersebut yang menyebabkan semakin sedikitnya penanaman sengon Solomon di Indonesia.

Dilain pihak, pertumbuhan sengon Solomon yang sangat cepat tersebut masih terkendala dengan adanya penyakit karat tumor (gall rust) yang menyerang jenis sengon. Proses terjadinya penyakit dapat berlangsung apabila ada tiga faktor yang saling berinteraksi yaitu adanya penyebab penyakit, adanya tanaman inang yang rentan dan kondisi lingkungan yang mendukung proses terjadinya penyakit. Penelitian sebelumnya pada uji keturunan sengon dari berbagai provenan memperlihatkan bahwa tingkat serangan penyakit karat tumor terbesar ditunjukkan oleh provenan sengon
Solomon sebesar $0,85 \%$, dengan intensitas serangan $0,51 \%$ (Setiadi $d k k ., 2014$ ).

Berdasarkan hal tersebut, maka dibutuhkan tanaman sengon yang memiliki produktivitasnya tinggi dan toleran terhadap penyakit. Penelitian khusus tentang respon sengon Solomon terhadap pertumbuhan dan penyakit karat tumor belum dilakukan. Balai Besar Penelitian Bioteknologi dan Pemuliaan Tanaman Hutan Yogyakarta pada tahun 2011, telah melakukan pengendalian penyakit melalui introduksi sumber genetik, salah satunya dengan membangun tegakan provenan sengon Solomon di Bondowoso, Jawa Timur. Benih sengon Solomon diimport dari PT Kolombangara Forest Products LTD, Honiara Solomon Islands. Adapun tujuan dari penelitian ini adalah memberikan informasi tentang pertumbuhan sengon Solomon dan ketahanannya terhadap serangan penyakit karat tumor.

\section{METODE PENELITIAN}

\section{A. Tegakan provenan Sengon Solomon}

Plot penelitian tegakan provenan sengon Solomon dibangun pada tahun 2011 pada Kawasan Hutan Dengan Tujuan Khusus (KHDTK) Balai Besar Penelitian Bioteknologi dan Pemuliaan Tanaman 
Hutan Yogyakarta di Bondowoso. Hutan penelitian tersebut terletak di Desa Wringin Anom, Kecamatan Sukosari, Kabupaten Bondowoso, Jawa Timur. Materi genetik yang digunakan dalam plot uji ini berasal dari 1 provenan yang terdiri dari 25 famili. Tegakan provenan sengon Solomon disusun dengan menggunakan rancangan baris kolom yang terdiri atas 25 famili dari 1 provenan dengan 8 ulangan, 4 pohon per plot (tree plot) dengan jarak tanam $3 \mathrm{~m} \times 2 \mathrm{~m}$.

Plot penelitian tersebut memiliki tipe iklim B dengan rerata curah hujan sebesar $2400 \mathrm{~mm} /$ tahun. Musim hujan mulai bulan November sampai dengan April dengan suhu terendah $17^{\circ} \mathrm{C}$ dan suhu tertinggi $30^{\circ} \mathrm{C}$. Jenis tanahnya bertekstur sedang yang meliputi lempung, lempung berdebu dan lempung liat berpasir. Tapak tergolong datar, terletak pada ketinggian tempat $800 \mathrm{~m}$ di atas permukaan laut (Setiadi dan Susanto, 2012). Penelitian pengamatan secara periodik setiap enam bulan dilakukan sejak bulan Mei 2011 sampai umur 18 bulan. Alat penelitian yang digunakan adalah galah ukur untuk mengukur tinggi pohon dan kaliper untuk mengukur diameter batang.

\section{B. Pengukuran}

Pertumbuhan yang diukur dalam penelitian ini adalah tinggi pohon dan diameter batang. Ketahanan serangan penyakit karat tumor diukur menggunakan sistem skoring dari 1 sampai 6 disajikan pada Tabel 1, untuk intensitas dan luas serangan penyakit karat tumor didasarkan atas kriteria tingkat keparahan serangan disajikan pada Tabel 1.

Tabel 1. Skoring gejala penyakit karat tumor pada tanaman sengon

\begin{tabular}{|c|c|}
\hline $\begin{array}{l}\text { Skoring } \\
\text { (scoring) }\end{array}$ & $\begin{array}{l}\text { Keterangan gejala (description of } \\
\text { symptoms) }\end{array}$ \\
\hline 6 & $\begin{array}{l}\text { Tanaman sehat, tidak ada gejala } \\
\text { (healthy plants, no symptoms) }\end{array}$ \\
\hline 5 & $\begin{array}{l}\text { Ada gejala pada pucuk batang dan } \\
\text { anak daun pada pucuk (there are } \\
\text { symptoms in stems and leaf buds } \\
\text { on the shoots) }\end{array}$ \\
\hline 4 & $\begin{array}{l}\text { Ada gejala pada cabang dan } \\
\text { ranting (there are symptoms of the } \\
\text { branches and twigs) }\end{array}$ \\
\hline 3 & $\begin{array}{l}\text { Ada penyakit karat tumor pada } \\
\text { cabang dan atau ranting (there was } \\
\text { gall rust disease on branches or } \\
\text { twigs) }\end{array}$ \\
\hline 2 & $\begin{array}{l}\text { Ada penyakit karat tumor pada } \\
\text { cabang dan atau ranting serta } \\
\text { batang (there are gall rust disease } \\
\text { in or twigs and branches and } \\
\text { trunks) }\end{array}$ \\
\hline 1 & $\begin{array}{l}\text { Tanaman kering atau mati karena } \\
\text { penyakit karat tumor (dried } \\
\text { or dead plants due to gall rust } \\
\text { disease) }\end{array}$ \\
\hline
\end{tabular}

\section{Analisis data}

Analisis data dilakukan untuk mengetahui persen hidup tanaman, rerata pertumbuhan dan mengetahui pengaruh 
sumber benih pada kedua sifat yang diukur. Model dari analisis sidik ragam yang digunakan sebagai berikut :

$$
\left.\mathrm{Y}_{\mathrm{ijk} k}=\mu+\mathrm{B}_{\mathrm{i}}+\underset{\mathrm{il}}{\mathrm{R}(\mathrm{B})_{\mathrm{ij}}}+\mathrm{C} \mathrm{C}_{\mathrm{ijk}}+\mathrm{B}\right)_{\mathrm{ik}}+\mathrm{F}+\mathrm{F}(\mathrm{BF})
$$

Keterangan $=$

$\mathrm{Y}_{\mathrm{ijk} 1} \quad=$ adalah rata-rata plot ke- ${ }_{1}$ pada baris ke- ${ }_{\mathrm{j}}$ kolom ke- ${ }_{\mathrm{k}}$ dalam ulangan ke- ${ }_{\mathrm{i}}$ dari ke- ${ }_{1}$ dalam ulangan ke- ${ }_{\mathrm{i}}$

$\mu \quad=$ nilai rerata umum

$\mathrm{F} \quad=$ famili

$\mathrm{B}_{\mathrm{i}} \quad=$ pengaruh ulangan $\mathrm{ke}_{-}{ }_{\mathrm{i}}$

$\mathrm{R}(\mathrm{B})_{\mathrm{ij}}=$ pengaruh baris ke- ${ }_{\mathrm{i}}$ yang bersarang dalam ulangan ke- ${ }_{j}$

$\mathrm{C}(\mathrm{B})_{\mathrm{ik}}=$ pengaruh kolom $\mathrm{ke}_{\mathrm{i}_{\mathrm{i}}}$ yang bersarang dalam ulangan kei- ${ }_{\mathrm{k}}$

$\mathrm{F}(\mathrm{BF})_{\mathrm{il}}=$ pengaruh interaksi ulangan $\mathrm{ke}_{-}{ }_{\mathrm{i}}$ yang bersarang pada famili ke- ${ }_{1}$

$\varepsilon_{\mathrm{ijkl}}=$ eror random.

Data hasil pengukuran dianalisis dengan sidik ragam, apabila terdapat perbedaan yang nyata kemudian dilanjutkan dengan uji lanjutan menggunakan Duncan Multiple Range Test-DMRT. Untuk memperoleh homogenitas terhadap persen hidup tanaman, persentase luas serangan dan intensitas penyakit dilakukan transformasi persen (P) menjadi nilai arcussinus $\left(\sin ^{-}\right.$ 1 Pvalue). Sedangkan untuk mengetahui gejala serangan penyakit maka dilakukan pengamatan persentase luas serangan dan intensitas penyakit pada setiap plot pengamatan yang dihitung dengan rumus sebagai berikut (Rahayu dkk., 2009 dalam Baskorowati $d k k ., 2012)$ :

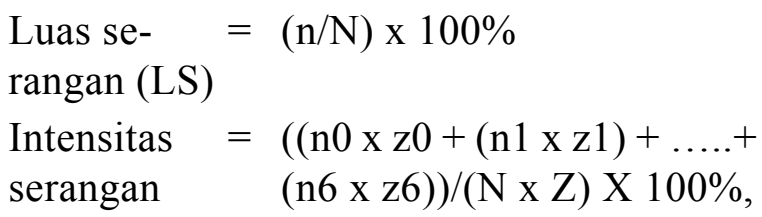
dimana:

n

$$
=\underset{\text { terinfeksi }}{\text { jumlah pohon yang }}
$$

$\mathrm{n} 0, \mathrm{n} 1, \mathrm{n} 2,=$ jumlah pohon dengan indeks $\mathrm{n} 3, \mathrm{nx} \quad 6$ skoring $1,2,3 \ldots \mathrm{x}$ $\mathrm{z} 0, \mathrm{z} 1, \mathrm{z} 2,=6$ skoring penyakit karat $\mathrm{z} 3, \mathrm{zx}$ tumor dengan indeks 6 $\mathrm{N}=$ jumlah total pohon dalam satu plot

$\mathrm{Z}=6$ skoring tertinggi

\section{HASIL DAN PEMBAHASAN}

\section{A. 1. Persen hidup dan Pertumbuhan}

Berdasarkan hasil pengamatan persen hidup, pengukuran tinggi dan diameter tanaman, serta pengamatan intensitas dan luas serangan penyakit karat tumor, dilakukan analisis sidik ragam, hasil analisis sidik ragam pengamatan persen hidup, pengukuran tinggi dan diameter tanaman disajikan pada Tabel 2 dan 3. 
Tabel 2. Analisis sidik ragam persentase hidup pada uji tegakan provenan sengon Solomon umur 6 - 18 bulan

\begin{tabular}{lcccc}
\hline \multirow{2}{*}{$\begin{array}{c}\text { Sumber variasi } \\
\text { (Sources of variation })\end{array}$} & $\begin{array}{c}\text { Derajat bebas } \\
(d f)\end{array}$ & \multicolumn{3}{c}{ Rata-rata Kuadrat (Mean squares) } \\
\cline { 3 - 5 } & 7 & $1061,20^{* *}$ & $483,69^{* *}$ & $1911,83^{* *}$ \\
\hline Blok $($ Block) & 5 & $410,58^{* *}$ & $516,86^{* *}$ & $709,07^{* *}$ \\
Baris $($ Row) & 4 & $934,30^{* *}$ & $813,20^{* *}$ & $1304,92^{* *}$ \\
Kolom $($ Coulum $)$ & 24 & $867,91^{* *}$ & $776,07 * *$ & $2037,85^{* *}$ \\
Famili (Family) & 759 & 98,02 & 138,49 & 265,22 \\
Eror (Error) & & &
\end{tabular}

Keterangan (remarks) : **= berbeda nyata pada taraf uji 1\% (highly significant different at 1\% level)

Tabel 3. Analisis sidik ragam pertumbuhan tinggi dan diameter pada uji tegakan provenan sengon Solomon umur 6 - 18 bulan

\begin{tabular}{cc}
\hline Sumber variasi & Rata-rata Kuadrat (Mean squares) Derajat bebas $(d f)$ \\
(Sources of variation) & 18 bulan (month)12 bulan $($ month $) 6$ bulan $($ month $)$ \\
\hline
\end{tabular}

\section{Tinggi (Height)}

Blok (Block)

Baris (Row)

Kolom (Coulum)

Famili (Family)

Blok (Block)*Famili (Family)

Eror (Error)

\section{Diameter (Diameter)}

Blok (Block)

Baris (Row)

Kolom (Coulum)

Famili (Family)

Blok (Block)*Famili (Family)

Eror (Error)

$$
\begin{aligned}
& 44,81 * * 34,12 * * 3,60 * * 7 \\
& 3,96 * * 4,15 * * 1,20 * * 33 \\
& 3,14 * * 2,23 * * 0,58 * * 32
\end{aligned}
$$

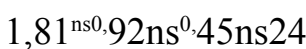

$$
\begin{aligned}
& 2,65 * * 1,94 * * 0,70 * * 104 \\
& 1,700,960,35104
\end{aligned}
$$

$$
\begin{gathered}
55,80 * * 44,46 * * 9,39 * * 7 \\
5,58 * * 4,86 * * 2,05 * * 33 \\
3,00 * * 4,40 * * 0,98 * * 32 \\
3,14^{\mathrm{ns} 2}, 06 \mathrm{~ns}^{0,76 \mathrm{~ns} 24} \\
3,90 * * 2,92 * * 1,12 * * 104 \\
2,831,840,65104
\end{gathered}
$$

Keterangan (remarks) :

$* *$ = berbeda nyata pada taraf uji $1 \%$ (highly significant different at $1 \%$ level);

$\mathrm{ns}=$ tidak berbeda nyata pada taraf uji 5\% (non significant different at 5\% level) 
Hasil analisis sidik ragam untuk persen hidup tanaman umur 6-18 bulan memperlihatkan adanya perbedaan yang nyata diantara famili uji. Hal ini menunjukkan adanya variasi diantara famili uji, sehingga memungkinkan peningkatan genetik dalam memperbaiki pertumbuhan tanaman (Tabel 3). Persen hidup familifamili sengon Solomon yang berasal dari 1 provenan berkisar antara 75\% hingga 90\% dengan persentase hidup secara keseluruhan pada umur 6 bulan $(84,83 \%)$, umur 12 bulan $(83,26 \%)$ dan umur 18 bulan $(81,05 \%)$. Persentase hidup tanaman tertinggi pada umur 6 sampai 18 bulan dimiliki oleh famili 5, 11, 19, dan 23 mencapai 90\%, sedangkan persentase hidup tanaman terendah dimiliki oleh famili $14(67,50 \%)$, famili 7 (71,25\%) dan famili $2(73,12 \%)$. Kemampuan daya adaptasi bervariasi antar famili, namun demikian semua famili dapat tumbuh dan beradaptasi dengan kondisi lingkungan di Bondowoso. Kemampuan tumbuh famili 5, 11, 19, dan 23 memiliki tingkat ketahanan hidup lebih tinggi dibandingkan dengan famili lainnya; sedangkan kemampuan hidup terendah ditunjukkan oleh famili 14, 7 dan 2.

Bervariasinya persen hidup tanaman pada uji tegakan benih provenan sengon Solomon di Bondowoso, Jawa Timur kemungkinan karena jenis ini termasuk jenis eksotik dengan kondisi lingkungan uji berbeda dengan tempat tumbuh asalnya, sehingga tanaman tersebut memerlukan waktu untuk menyesuaikan diri dengan kondisi lingkungan setempat. Hakim (2008) menyatakan bahwa daya hidup merupakan indikasi kemampuan tumbuh tanaman terhadap kondisi lingkungan; daya hidup ini merupakan salah satu kriteria seleksi, terutama pada waktu introduksi jenis pada lahan yang memiliki perbedaan lingkungan dengan tempat asalnya. Disamping faktor tempat tumbuh, kompetisi antar famili dan peranan pengelolaan plot uji juga menentukan keberhasilan pertumbuhan tegakan provenan tersebut. Berdasarkan analisis rata-rata persen hidup tanaman pada tegakan provenan sengon Solomon umur 18 bulan adalah $81,05 \%$. Rerata persen hidup tersebut hampir sama dengan penelitian terdahulu berkisar antara $75 \%$ sampai dengan 86,53\% (Gusdwiyanti, 2009; Ismail dan Hadiyan, 2008; Hadiyan, 2010).

Berdasarkan analisis laju pertumbuhan tinggi dan diameter pohon menunjukkan adanya peningkatan yang cukup tinggi pada umur 6, 12 dan 18 bulan seperti yang disajikan pada grafik Gambar 1 . 
Dari Grafik gambar 1 terlihat bahwa peningkatan pertumbuhan tinggi dan diameter pada setiap periode pengukuran dari masing-masing famili menunjukkan relatif lebih seragam. Rata-rata pertumbuhan tinggi dan diameter pada umur 6 bulan sebesar $(2,43 \mathrm{~m} ; 2,97 \mathrm{~cm})$, umur 12 bulan $(4,75 \mathrm{~m} ; 5,56 \mathrm{~cm})$ dan umur 18 bulan $(7,36$ $\mathrm{m} ;$ 7,40 cm). Mukmin (2004) melaporkan hasil penelitian uji keturunan sengon dari 18 famili umur 6 bulan di Taman Hutan Cikabayan Darmaga, Bogor rata-rata pertumbuhan tinggi $(0,92 \mathrm{~m})$ dan diameter $(1,36 \mathrm{~cm})$. Pada keragaman sengon Solomon pada uji keturunan di Cirangsad, Jasinga, Bogor pada umur 2 tahun menunjukkan rata-rata tinggi sebesar 5,26 $\mathrm{m}$ dan diameter sebesar 6,5 cm (Gusdwiyanti, 2009).

Pertumbuhan tersebut lebih rendah dibandingkan dengan tegakan provenan sengon Solomon umur 18 bulan di Bondowoso (Jawa Timur). Pertumbuhan tinggi dan diameter sengon Solomon umur 2 tahun di Temanggung Jawa Tengah mempunyai rata-rata tinggi dan diameter sebesar $8 \mathrm{~m}$ dan diameter sebesar $16 \mathrm{~cm}$ (Hardiyanto, 2010).

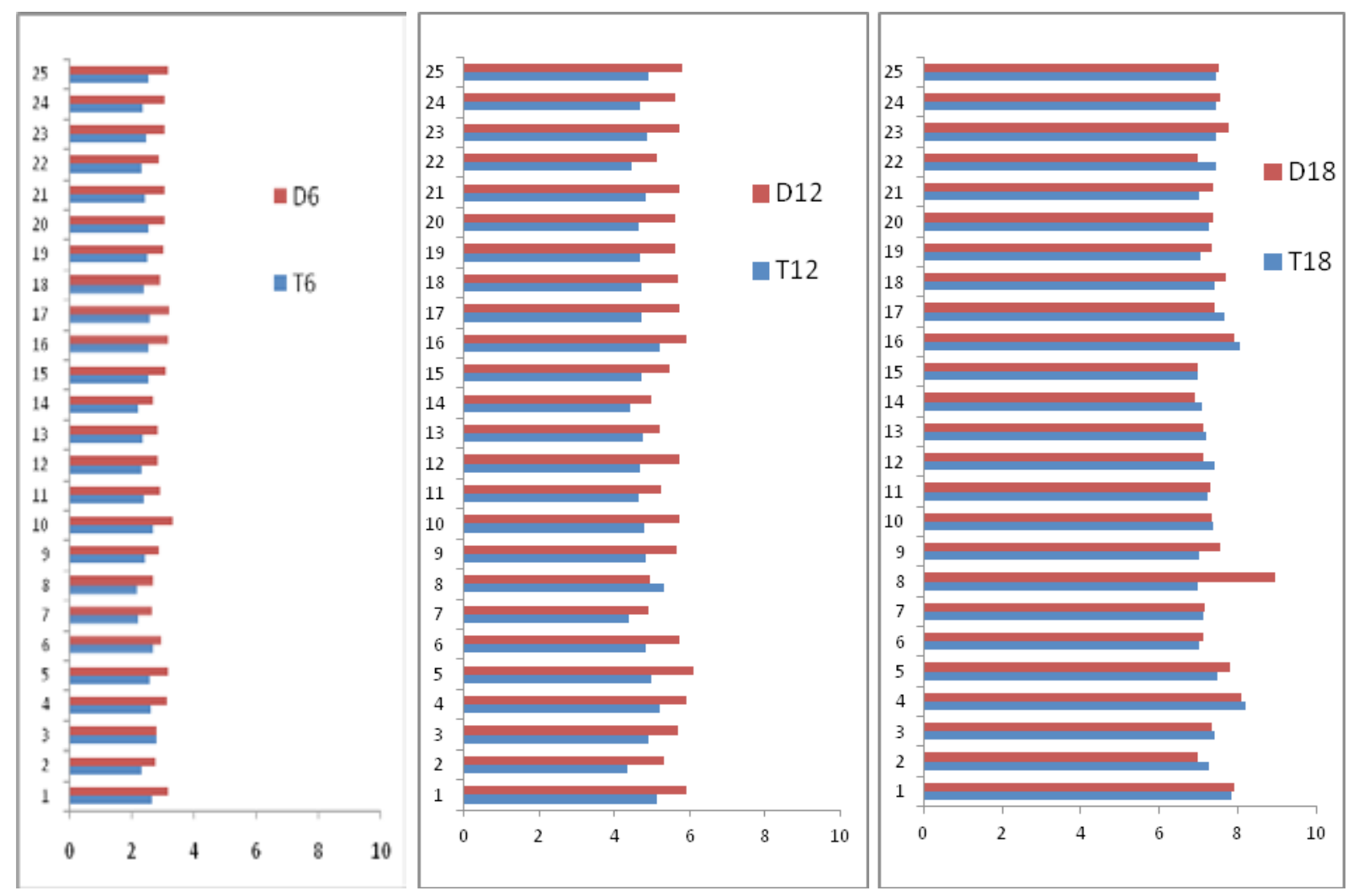

Gambar 1. Grafik Rerata pertumbuhan tinggi (m) dan diameter (cm) sengon Solomon pada umur 6-18 bulan 
Laju pertumbuhan pada tegakan benih provenan sengon Solomon di Bondowoso, Jawa Timur mempunyai trend pertumbuhan sejalan dengan bertambahnya umur, hal ini sejalan dengan penelitian sengon yang dilakukan Riyanto dan Pamungkas (2010) di Kediri, Jawa Timur bahwa pada umur 0-5 tahun tanaman sengon mempunyai trend pertumbuhan yang sangat pesat. Sedangkan sengon di Palembang memiliki tren pertumbuhan diameter maksimal adalah pada saat mencapai umur 5 tahun (Riyanto dan Kusnandar, 1994). Peningkatan pertumbuhan cukup tinggi dan relatif seragam, diduga keragaman genetik dari individu-individu penyusun tegakan provenan tersebut mempunyai basis genetik yang relatif rendah, karena tegakan benih provenan sengon Solomon hanya dari satu provenan, dimana letak geografinya lebih seragam diasumsikan mempunyai kemampuan adaptasi yang seragam.

Keragaman genetik merupakan perbedaan gen yang terkandung dalam individu suatu populasi dan berhubungan dengan kemampuan beradaptasi suatu individu dalam mengalami perubahan selama proses perkembangannya. Kemampuan beradaptasi tersebut dapat diamati dari dua parameter, yaitu secara fenotip (pertumbuhan, kesehatan, reproduksi) dan parameter genetik yang tidak secara langsung berkaitan dengan adaptabilitas (Finkedley, 2005).

Hasil analisis keragaman pertumbuhan tinggi dan diameter pada setiap periode pengukuran disajikan pada Tabel 3 , hasil tersebut menunjukkan bahwa diantara famili untuk sifat tinggi dan diameter batang pada setiap periode pengukuran (umur 6, 12 dan 18 bulan) tidak menunjukkan perbedaan yang nyata (terlihat dari Grafik 1). Hal tersebut dikarenakan asal usul famili tersebut dari satu provenan yaitu Solomon, dimana Kepulauan Solomon merupakan kepulauan kecil-kecil yang jarak antar pulaunya sangat dekat. Hal ini memungkinkan sengon Solomon yang berkerabat dekat karena persilangan (outcrossing) masih terjadi sehingga individu-individu dari tempat yang berbeda-beda tersebut menghasilkan keturunan yang mempunyai karakteristik yang sama.

Menurut Zobel dan Talbert (1984) bahwa provenan atau ras geografik merupakan area geografi alami dimana benih atau propagul dikumpulkan. Adanya provenan ini disebabkan oleh suatu jenis tanaman 
yang mempunyai sebaran alami di beberapa tempat dan mempunyai kondisi lingkungan yang sangat spesifik, sehingga memberikan penampilan yang berbeda di antara ras geografik tersebut. Apabila penampilan dari sumber benih alami tersebut tidak memberikan perbedaan yang nyata, diduga merupakan satu provenan yang tersebar secara berkesinambungan. Keragaman genetik sengon yang ada di Jawa menurut beberapa hasil penelitian tergolong rendah (Seido dan Widyatmoko, 1993; Suharyanto $d k k ., 2002)$. Selanjutnya dikatakan bahwa suatu jenis tanaman seharusnya mempunyai dasar keragaman genetik yang cukup untuk dapat beradaptasi dengan perubahan lingkungan (Rimbawanto dan Widyatmoko, 2006). Diantara ulangan dan baris di dalam ulangan pada setiap periode pengukuran untuk kedua sifat yang diukur menunjukkan adanya keragaman. Namun perbedaan kolom di dalam ulangan pada setiap periode pengukuran tidak selalu menunjukkan adanya keragaman. Adanya keragaman dari kedua sifat yang diukur yang disebabkan oleh baris di dalam ulangan, hal ini menandakan bahwa di dalam ulangan terdapat perbedaan lingkungan tempat tumbuh searah baris. Sungguhpun dalam tegakan yang seumur pada tempat tumbuh yang sangat seragam, keragaman diantara individu pohon tetap dapat dijumpai (Hardiyanto, 2000).

\section{B. Penyakit karat tumor}

Adanya epedemi penyakit karat tumor dapat menjadi ancaman yang dapat mengakibatkan penurunan produk kayu sengon secara besar-besaran pada tahuntahun mendatang (Rahayu, 2008). Dari hasil pengamatan serangan penyakit karat tumor terlihat bahwa gejala serangan tampak pada ranting, cabang, batang, pucuk batang dan anak daun pada pucuk. Besarnya nilai skoring, intensitas dan luas serangan penyakit per blok merupakan rata-rata dari besarnya nilai skoring, intensitas dan luas serangan penyakit masing-masing individu pohon yang terdapat di dalam plot pada provenan yang bersangkutan. Data hasil pengukuran rata-rata nilai skoring kerusakan penyakit karat tumor disajikan pada Grafik 2. Dari grafik tersebut memperlihatkan bahwa pada umur 6 bulan, tanaman sengon Solomon tidak terserang penyakit karat tumor. Rata-rata intensitas dan luas serangan penyakit karat tumor disajikan pada Grafik 3. Sedangkan hasil analisis sidik ragam skoring, intensitas dan luas serangan penyakit karat tumor disajikan pada Tabel 4. 


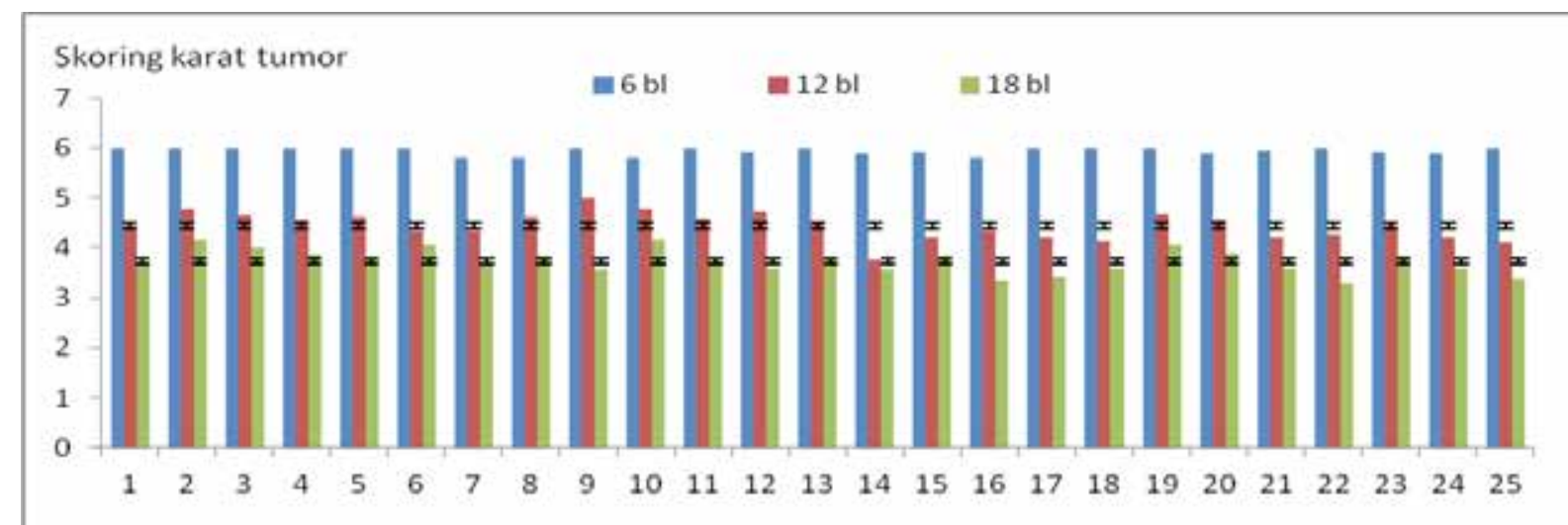

Keterangan: semakin besar nilai skoring, semakin sehat tanaman (Remarks: the greater the value of scoring, the healthier plants)

Gambar 2. Grafik Rata-rata skoring kerusakan serangan penyakit karat tumor pada umur 6-18 bulan
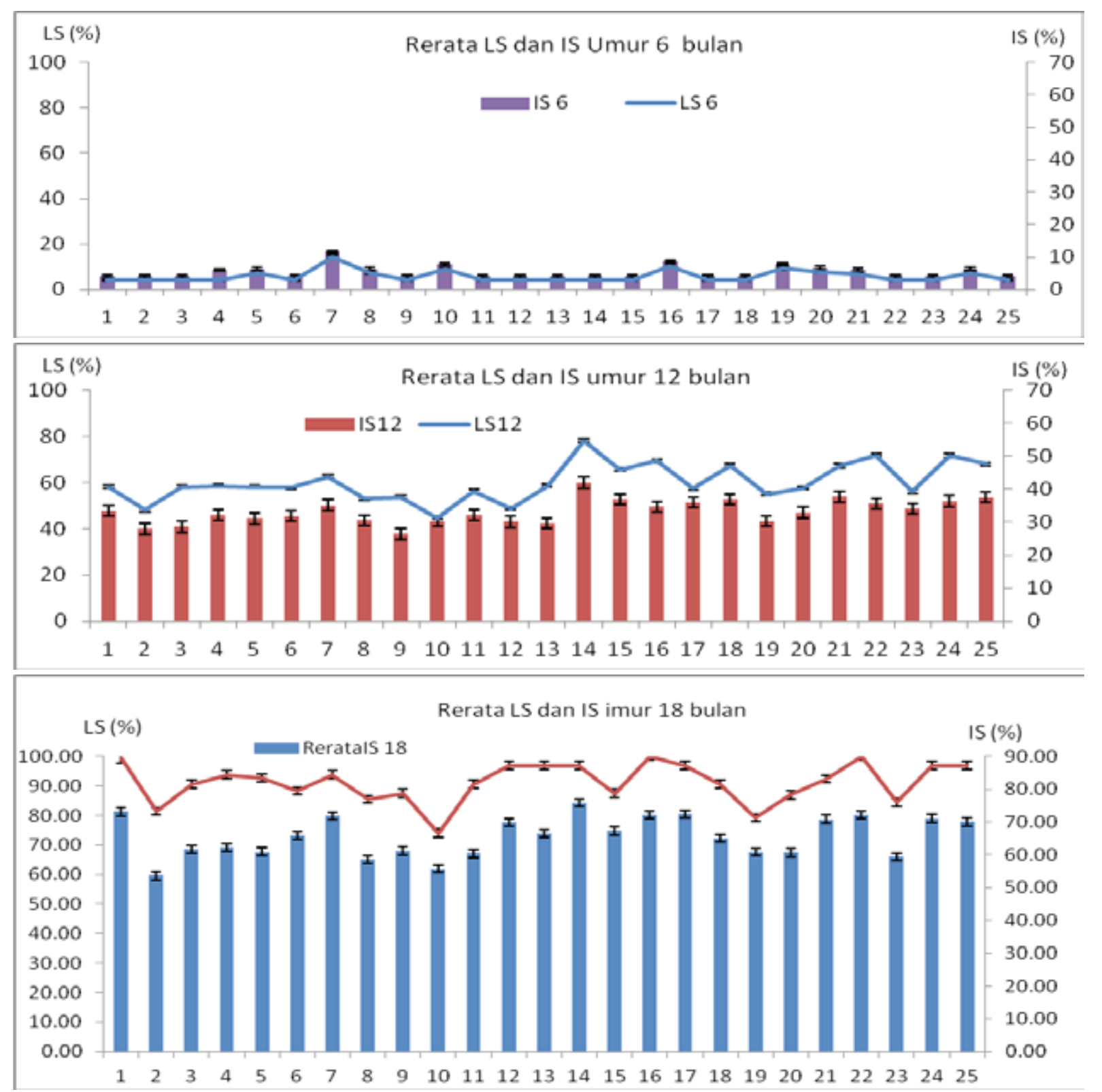

Gambar 3. Grafik Rata-rata intensitas dan luas serangan penyakit karat tumor umur 6-18 bulan (The average of disease severity and incidence of gall rust disease at 6-18 old) 
Tabel 4. Analisis sidik ragam skoring, intensitas dan luas serangan penyakit karat tumor pada umur 6 18 bulan

\begin{tabular}{|c|c|c|c|c|c|c|c|c|c|c|}
\hline \multirow{3}{*}{$\begin{array}{c}\text { Sumber } \\
\text { variasi } \\
\text { (Sources } \\
\quad \text { of } \\
\text { variation }\end{array}$} & \multirow[b]{3}{*}{$\begin{array}{l}\mathrm{Db} \\
(d f)\end{array}$} & \multicolumn{9}{|c|}{ Rata-rata kuadrat (Means square) } \\
\hline & & \multicolumn{3}{|c|}{6 bulan (months) } & \multicolumn{3}{|c|}{12 bulan (months) } & \multicolumn{3}{|c|}{18 bulan (months) } \\
\hline & & $\begin{array}{c}\text { Skor } \\
\text { (scored) }\end{array}$ & $\begin{array}{l}\text { Intensitas } \\
\text { penyakit } \\
\text { (severity) }\end{array}$ & $\begin{array}{l}\text { Luas } \\
\text { serangan } \\
\text { (inci- } \\
\text { dence) }\end{array}$ & $\begin{array}{c}\text { Skor } \\
\text { (scored) }\end{array}$ & $\begin{array}{l}\text { Intensitas } \\
\text { penyakit } \\
\text { (severity) }\end{array}$ & $\begin{array}{c}\text { Luas } \\
\text { serangan } \\
\text { (incidence) }\end{array}$ & $\begin{array}{c}\text { Skor } \\
\text { (scored) }\end{array}$ & $\begin{array}{l}\text { Intensitas } \\
\text { penyakit } \\
\text { (severity) }\end{array}$ & $\begin{array}{c}\text { Luas } \\
\text { serangan } \\
\text { (inci- } \\
\text { dence) }\end{array}$ \\
\hline $\begin{array}{l}\text { Blok } \\
\text { (Block) }\end{array}$ & 7 & $0,269^{\mathrm{ns}}$ & $174,11 * *$ & $334,94 * *$ & $4,165^{* *}$ & $635,09 * *$ & $4161,42 * *$ & $4,896^{* *}$ & $149,70 * *$ & $2145,57 * *$ \\
\hline $\begin{array}{l}\text { Famili } \\
\text { (Family) }\end{array}$ & 24 & $0,165^{\mathrm{ns}}$ & $122,30 * *$ & $235,39 * *$ & $2,000 * *$ & $417,90 * *$ & $2022,28 * *$ & $1,441 * *$ & $546,41 * *$ & $1309,74 * *$ \\
\hline $\begin{array}{l}\text { Blok } \\
(\text { Block)* } \\
\text { Famili } \\
\text { (Family) }\end{array}$ & 162 & $0,185^{\mathrm{ns}}$ & $87,61 * *$ & $169,09 * *$ & $1,600^{\mathrm{ns}}$ & $340,30 * *$ & $1759,02 * *$ & $0,658 * *$ & $665,14 * *$ & $1260,42 * *$ \\
\hline $\begin{array}{l}\text { Eror } \\
\text { (Error) }\end{array}$ & 764 & 0,168 & 1,670 & 3,212 & 1,326 & 2,298 & 22,581 & 0,658 & 8,946 & 4,0985 \\
\hline
\end{tabular}

Keterangan (remarks) : ** = berbeda nyata pada taraf uji 1\% (highly significant different at $1 \%$ level) $\mathrm{ns}=$ tidak berbeda nyata pada taraf uji 5\% (non significant different at 5\% level)

Hasil analisis sidik ragam untuk skoring, intensitas dan luas serangan penyakit (Tabel 4) menunjukkan perbedaan yang nyata antara famili yang diuji pada periode pengukuran umur 12 dan 18 bulan, kecuali pada pengukuran umur 6 bulan, dimana tingkat kerusakan akibat serangan karat tumor masih sedikit bahkan masih ada famili yang belum terserang. Hasil uji menunjukkan bahwa famili-famili no, 2, 8 dan 23 menunjukkan skoring kerusakan serangan serta intensitas penyakit yang paling kecil, dengan indikasi ketahanan yang moderat, dibandingkan dengan famili yang lainnya dengan indikasi ketahanan agak rentan. Hal ini merupakan suatu petunjuk bahwa ketahanan famili-famili terhadap serangan penyakit karat tumor dapat berubah dengan berubahnya umur dan lingkungan tanaman. Seperti terlihat pada Grafik 3 yang ditunjukkan dengan nilai skoring, pada umur 6 bulan beberapa famili masih relatif tahan terhadap serangan penyakit karat tumor, seiring dengan bertambahnya umur tanaman yaitu pada pengamatan umur 12 dan 18 bulan semua famili terserang oleh penyakit karat tumor. Begitu juga dengan penyakit bercak daun pada tanaman Ampupu bahwa ketahanan provenan terhadap serangan penyakit tersebut dapat berubah dengan berubahnya umur dan lingkungan (Rahayu dkk., 1998). Berdasarkan hasil perhitungan nilai heritabilitas skoring tingkat kerusakan oleh penyakit karat tumor 
pada tegakan provenan sengon Solomon adalah 0,21. Hal tersebut menunjukkan bahwa tingkat kerusakan penyakit oleh penyakit karat tumor, $21 \%$ dikendalikan oleh faktor provenan dan 79\% dikendalikan oleh faktor lingkungan. Setiadi $d k k$., (2014) melaporkan pada uji keturunan sengon dari berbagai provenan bahwa luas serangan penyakit karat tumor terbesar ditunjukkan oleh provenan sengon Solomon sebesar $0,85 \%$, dengan intensitas serangan $0,51 \%$. Meskipun penyakit karat tumor secara umum pada penelitian ini menunjukkan indikasi agak rentan dan moderat, namun seiring berjalannya waktu dan bertambahnya umur tanaman ada indikasi bahwa penyakit karat tumor yang menyerang pada bagian ujung cabang atau ranting bisa dipangkas dan penyakit karat tumor tersebut tidak mengganggu batang pokoknya, sehingga tanaman bisa tumbuh normal kembali dan diharapkan perlu mendapat perhatian secara khusus dan menjadi pertimbangan apabila akan digunakan sebagai pohon induk atau sumber biji.

Bagian tanaman yang terserang penyakit karat tumor akan mengalami perubahan bentuk dan pembengkakan, semakin lama pembengkakan yang berada di ranting, cabang dan batang akan menjadi benjolan yang kemudian menjadi bintilbintil atau disebut tumor. Ranting atau cabang yang terkena serangan karat tumor daunnya akan menguning dan gugur sebelum waktunya (Ngatiman dan Anggraeni, 2006). Hampir mirip dengan serangan penyakit bercak daun yang menyerang tanaman Eucalyptus sp dimana penyerangannya sangat cepat dan apabila tidak dikendalikan dapat mengakibatkan matinya jaringan daun, selanjutnya daun kemudian kering dan rontok (Suharti, 1990). Akibat dari hal tersebut proses fotosintesa tidak maksimum, sehingga pertumbuhan tanaman akan mengalami penghambatan, bahkan dapat terjadi batang patah dan berakhir dengan kematian. Keadaan serangan penyakit karat tumor pada tegakan benih provenan sengon Solomon seperti disajkan pada Gambar 1. 


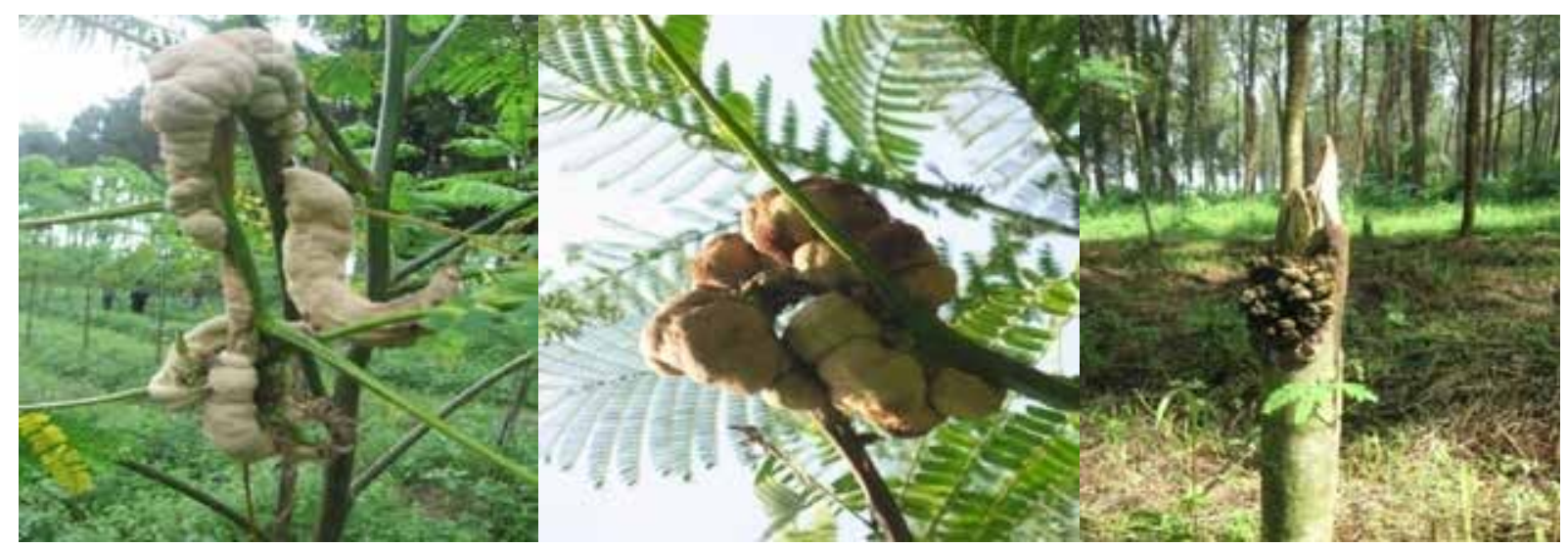

Gambar 4. Serangan penyakit karat tumor pada cabang dan batang tegakan provenan Solomon di Bondowoso, Jawa Timur

Salah satu upaya pengendalian penyakit karat tumor pada sengon telah dilakukan di Panjalu, Ciamis, Jawa Barat dengan menggunakan blerang, kapur dan garam (campuran blerang dan garam /10:1) hasilnya cenderung menunjukkan aktivitas penghambatan pertumbuhan karat tumor tertinggi dan paling banyak menurunkan jumlah penyakit karat tumor sampai bulan ke-2 (Anggraeni $d k k$., 2010). Kaitannya suatu jenis tanaman dengan basis keragaman genetik yang rendah terhadap kemungkinan terserangnya penyakit, Rimbawanto (2008) melaporkan bahwa keragaman genetik yang rendah meningkatkan resiko terhadap serangan penyakit, lebih-lebih karena pemuliaan pohon lebih menekankan pada peningkatan riap dan bukan pada ketahanan terhadap hama dan penyakit. Begitu pula bila dilihat dari potensi terjadinya hibridisasi, apabila terjadi hibrid antara famili yang agak rentan dengan famili yang rentan, dikhawatirkan akan menghasilkan individuindividu yang potensial rentan pula. Sehingga informasi genetik akan ketahanan terhadap penyakit karat tumor ini sangat diperlukan.

\section{KESIMPULAN DAN SARAN}

\section{A. Kesimpulan}

Hasil evaluasi awal uji tegakan provenan sengon Solomon sampai umur 18 bulan menunjukkan bahwa rerata persen hidup berkisar antara 75\% hingga 90\% pada umur 6 bulan $(84,83 \%), 12$ bulan $(83,26 \%)$ dan 18 bulan $(81,05 \%)$. Rerata tinggi dan diameter umur 6 bulan $(2,42 \mathrm{~m}, 2,97 \mathrm{~cm})$, 12 bulan $(4,74 \mathrm{~m}, 5,56 \mathrm{~cm})$, dan 18 bulan $(7,35 \mathrm{~m}, 7,39 \mathrm{~cm})$. Analisis keragaman terhadap tinggi, diameter, skoring, intensitas dan luas serangan penyakit menunjukkan perbedaan yang tidak nyata antara famili 
yang diuji. Famili-famili no, 2; 8; dan 23

menunjukkan skoring kerusakan serangan serta intensitas penyakit yang paling kecil, dengan indikasi ketahanan yang moderat, dibandingkan dengan famili yang lainnya dengan indikasi ketahanan agak rentan. Dengan demikian famili-famili tersebut perlu mendapat perhatian secara khusus dan menjadi pertimbangan apabila akan digunakan sebagai pohon induk atau sumber biji.

\section{B. Saran}

Evaluasi uji tegakan provenan sengon Solomon secara periodik mengenai pengamatan pertumbuhan dan ketahanan terhadap serangan penyakit karat tumor masih perlu dilakukan, hal ini dilakukan untuk mendapatkan informasi laju pertumbuhan pohon dan nilai parameter genetiknya hingga akhir daur serta dalam rangka menentukan strategi pemuliaannya dari jenis sengon Solomon yang relatif masih baru dikembangkan di Indonesia.

\section{DAFTAR PUSTAKA}

Anggraeni, I. B. Dendang dan N.E. Lelana, 2010. Pengendalian Penyakit Karat Tumor (Uromycladium tepperianum) Pada Sengon (Falcataria mollucana) Di Panjalu, Ciamis, Jawa Barat. Jurnal Penelitian Hutan Tanaman Vol. 7 No.
5. (273-278).

Baskorowati, L., Susanto, M. and M. Charomaini. 2012. Genetic Variability in Resistance of Falcataria moluccana (Miq.) Barneby\&J.W. Grimes to Gall Rust Disease. Journal of Forestry Research Vol.9 No. 1. (1-9).

Finkeldey R. 2005. Pengantar Genetika Hutan Tropis. Djamhuri E, Siregar IZ, Siregar UJ Kertadikara AW, penerjemah. Bogor: Fakultas Kehutanan. Institut Pertanian Bogor. Terjemahan dari: An Introduction to Tropical Forest Genetics.

Gusdwiyanti, F. 2009. Keragaman sengon Solomon (Paraserianthes falcataria L. Nielsen) Pada Uji Keturunan di Hutan Percobaan Cirangsad, Bogor, Jawa Barat (Skripsi). Departemen Manajemen Hutan, Fakultas Kehutanan, Institut Pertanian Bogor (tidak diterbitkan).

Gunawan, Rohandi A., Pieter, L.A., 2013. Laporan hasil penelitian populasi pemuliaan Sengon. Balai Teknologi Agroforestri Ciamis, Jawa Barat. Tidak dipublikasikan.

Hadiyan, Y. 2010. Evaluasi Pertumbuhan Awal Kebun Benih Semai Uji Keturunan Sengon (Falcataria moluccana) Umur 4 Bulan Di Cikampek, Jawa Barat. Jurnal Pemuliaan Tanaman Hutan Vol 4 No 2. Balai Besar Penelitian Bioteknologi dan Pemuliaan Tanaman Hutan.

Hidayat, J., D. Iriantono,. P. Oshsner 2002. Informasi Singkat Benih. Forest Seed Project. Bandung. Indonesia.

Hakim, L. 2008. Variasi Pertumbuhan Empat Provenan Ulin (Eusideroxylon zwageri T.et B.) Kalimantan. Junal Penelitian Hutan Tanaman . Vo.5 No. 2. (91-97).

Hardiyanto, E.B. 2000. Kuantitatif Genetik. Lecture notes on Training Course in Basic Forest Genetic. Indonesia Forest Seed Project and Faculty of Forestry Gajah Mada University. WanagamaWonogiri, 12-17 June 2000.

Hardiyanto, E.B. 2010. Faktor yang Berpengaruh pada Produktivitas dan Kualitas Kayu Sengon. Makalah disampaikan pada Pelatihan Penyakit Karat Tumor pada Sengon dan Pengelolaannya, 3-5 Agustus 2010, Fakultas Kehutanan UGM, Yogyakarta.

Ismail, B dan Hadiyan, Y. 2008. Evaluasi Awal 
Uji Keturunan Sengon (Falcataria moluccana) Umur 8 Bulan Di Kabupaten Kediri, Jawa Timur. Jurnal Penelitian Hutan Tanaman. Vo.2 No. 3. (287-293). Krisnawati, H., E.Varis., M. Kallio dan M. Kanninen. 2011. Paraserianthes falcataria (L.) Nielsen: Ekologi, Silvikultur dan Produktivitas. CIFOR. Bogor.

Mukmin, A. 2004. Uji Keturunan Saudara (Paraserianthes Falcataria L. Nielsen) Di Taman Hutan Blok Cikabayan (Skripsi). Departemen Manajemen Hutan, Fakultas Kehutanan, Institut Pertanian Bogor (tidak diterbitkan)

Ngatiman dan I. Anggraeni, 2006. Penyakit Bercak Daun Pada Tanaman Eukalyptus. Jurnal Penelitian Hutan Tanaman. Vol. 3 No. 3. (183-191).

Rimbawanto, A. 2008. Pemuliaan Tanaman dan Ketahanan Penyakit pada Sengon. Makalah Workshop Penanggulangan Serangan Karat Puru pada Tanaman Sengon. Balai Besar Penelitian Bioteknologi dan Pemuliaan Tanaman Hutan. (1-5).

Rimbawanto, A. dan AYPBC Widyatmoko. 2006. Keragaman Genetik Empat Populasi Intsia bijuga Berdasarkan Penanda RAPD dan Implikasinya bagi Program Konservasi Genetik. Jurnal Penelitian Hutan Tanaman . Vol.3 No. 3. (149-154).

Rahayu, S., Nor Aini, A.S., Lee, S., and G. Saleh., 2009. Responses of Falcataria mollucana seedlings of different seed sources to inoculation with Uromycladium tepperianum. Silvae Genetica. Vol.58 (62-68).

Rahayu, S. 2008. Penyakit karat tumor pada sengon. Makalah Workshop Serangan Karat Tumor pada Sengon. Balai Besar Penelitian Bioteknologi dan Pemuliaan Tanaman Hutan Yogyakarta. 19 Nopember 2008 (1-6).

Rahayu, S., Hani'in, O., A. Sulthoni. 1998. Evaluasi Awal Ketahanan Pertamanan Uji Provenans Eucalyptus urophylla Terhadap Penyakit Bercak Daun Di Tapak Sebulu, Samarinda. Bulletin Kehutanan No.34/1998. (1-10).

Riyanto, H.D. dan B.P. Pamungkas. 2010. Model Pertumbuhan Tegakan Hutan Tanaman
Sengon Untuk Pengelolaan Hutan. Teknologi Hutan Tanaman. Vol. 3 No. 3.(113-120).

Riyanto, H.D. dan E. Kusnandar. 1994. Kurva pertumbuhan dan laju pertumbuhan diameter sengon. Informasi Teknis Hasil Pengembangan Teknologi Reboisasi No. 6, 1994. Balai Teknologi Reboisasi Palembang.

Suharti, M. 1990. Penyakit bercak daun Eucalyptus deglupta di BKPH Cimanggu, Bandung Selatan. Buletin Penelitian Hutan Indonesia 525: (7-16).

Setiadi, D. M, Susanto dan L, Baskorowati. 2014. Ketahanan Serangan Penyakit Karat Tumor Pada Uji Keturunan Sengon (Falcataria moluccana) di Bondowoso, Jawa Timur. Jurnal Pemuliaan Tanaman Hutan. Yogyakarta (proses penerbitan)

Setiadi, D., M. Susanto. 2012. Variasi Genetik Pada Kombinasi Uji Provenan dan Uji Keturunan Araucaria cunninghamii di Bondowoso, Jawa Timur. Jurnal Pemuliaan Tanaman Hutan. Vol.6 No. 03. (157-166).

Suharyanto, Rimbawanto A, Isoda K. 2002. Genetic Diversity and Relationship Analysis on Paraserianthes falcataria Revealed by RAPD Marker. In A. Rimbawanto and M. Susanto (eds.). Proceedings International Seminar “ Advances in Genetic Improvement of Tropical Tree Species “. Yogyakarta: Centre for Forest Biotechnology and Tree Improvement

Seido, K and AYPBC Widyatmoko. 1993. Genetic Variation at Four Allozyme Loci I Paraserianthes falcataria at Wamena in Irian Jaya. Forest Tree Improvement Project Technical Report. Yogyakarta.

Trubusid. 2008. Trubus majalah pertanian Indonesia dari timur menggapai langit. http://www.trubus-online.co.id (25 Maret 2014).

Widhana S, IW. 2011. Model Dugaan Volume dan Riap Tegakan Sengon (Paraserianthes falcataria) Di Desa Suter, Kintamani, Bali. BPK Mataram. Agroteksos Vol.21 No.1 (29-38).

Zobel,B.and Talbert J., (1984). Applied Tree Improvement. 505 p. New York: John Wiley \& Sons, Inc. 